\title{
Research on the Implementation Path of Modern Apprenticeship in Higher Vocational Colleges
}

\author{
Qu Wujiang ${ }^{1}$, Huo Yanfei ${ }^{1}$ \\ ${ }^{1}$ Dalian Ocean University, Dalian, Liaoning 116300, China.
}

Keywords: Higher vocational college; modern apprenticeship; implementation path

\begin{abstract}
Talent training of modern apprenticeship aims at deepening school-enterprise cooperation, and school-enterprise cooperation in education, so as to improve the quality of skilled talent training. Based on the analysis of the connotation and relevant policies of modern apprenticeship, this paper analyzes the existing problems in the implementation of modern apprenticeship in higher vocational colleges, positively explores and proposes the implementation path of modern apprenticeship professional training.
\end{abstract}

\section{Introduction}

Higher professional education has been developing for more than 40 years since the 1980s. According to the social and economic development, the state has formulated a series of policies and systems to improve the quality of higher professional education training professionals. School-enterprise cooperation has a long history, but in the real implementation process, there always exists the phenomenon of "hot school and, cold enterprise". In 2014, the Ministry of Education issued the opinions on carrying out the experimental work of modern apprenticeship [1], aiming at further deepening school-enterprise cooperation and integration of production and education and improving the training quality of skilled talents through the implementation of the training mode of modern apprenticeship professionals.

\section{Connotation and Relevant Regulations and Policies of Modern Apprenticeship}

School-enterprise cooperation and integration of production and education are necessary ways to cultivate high-quality skilled talents. In order to further improve the quality of vocational personnel training and deepen the cooperation between schools and enterprises, the Ministry of Education issued the Opinions on the Pilot Work of Developing Modern Apprenticeship in 2014, and formulated the work program, the purpose of which is to improve the conformity between professional talents and professional posts in enterprises through the joint training of modern apprenticeship schools and enterprises, to integrate directly with the actual professional posts in enterprises, to further improve the mechanism of integration of production and education, and to innovate the training mode of skilled professionals.

Under the support and guidance of policy, modern apprenticeship is a modern career education talent cultivation model in which schools cooperate deeply with enterprises, such as students-oriented, joint training mode connecting professional teachers with enterprise masters, taking the initiative to adapt to the requirements of regional social and economic development and cultivate students' professional skills ${ }^{[2]}$. It is different from the previous talent cultivation customized. Modern apprenticeship focuses on the inheritance of professional skills. Schools and enterprises jointly set professional course standards, course systems and assessment systems, and jointly implement talent cultivation, which has the characteristics of "double-subject, double-border, double-teacher".

Professional personnel training mode of Modern apprenticeship helps to promote the industry, enterprise and government to participate in the process of talent cultivation and realize the following goals like the direct joint between major setup and local economic development, the joint between the curriculum and demand of industry enterprise, the joint of curriculum content, teaching process and professional standards even the production process. The organic integration of double certificate system (diploma and vocational certificate), thus improving the quality of personnel training of vocational colleges and universities. 
In order to further promote the effective implementation of the modern apprenticeship talent training model, the Ministry of education issued the opinions on deepening the vocational education teaching reform and comprehensively improving the quality of talent training (the Ministry of education [2015] No.6) in July 2015.The paper points out that we should deepen the reform of vocational education teaching, and actively promote the modern apprenticeship pilot of school-enterprise joint enrollment, joint training and integrated education ${ }^{[1]}$.The Ministry of education selected 165 units as the first modern apprenticeship pilot units and industry pilot units in August 2015 and the Ministry of education identified the second 203 modern apprenticeship pilot units in August 2017.

In January 2018, the General Office of the State Council issued "Several Opinions on Deepening the Integration of Industry and Education", proposing that we should deepen the reform of Vocational education, give full play to the important role of enterprises in educating people, encourage the exploration and promotion of mixed ownership, and allow enterprises to participate in running schools according to law and enjoy corresponding rights. In June 2018, the Ministry of education identified third batches of 402 modern apprenticeship units.

\section{Problems in the Mode of Training Modern Apprentices in Vocational Colleges}

Since the first batch of modern apprenticeship pilot projects in 2014, the pilot higher vocational colleges and secondary vocational schools have actively carried out the reform and practice of modern apprenticeship personnel training, and actively implement the modern apprenticeship pilot system of "recruiting students is recruiting workers, entering schools is factory" and other school-enterprise joint training. But in the real implementation process, just as the "Xinyu" phenomenon of modern apprenticeship in Jiangxi Province, the school-enterprise cooperation and the integration of production and education have appeared very embarrassing situation and the implementation of modern apprenticeship is difficult. The main problems are:

\subsection{Insufficient Understanding of Modern Apprenticeship}

For teachers and students of higher vocational colleges, what is a modern apprenticeship, what kind of school-enterprise cooperation can be called a modern apprenticeship, and to what extent which schoolenterprise cooperation can be called a modern apprenticeship, etc., are all lack of recognition ${ }^{[3]}$.For teachers with traditional ideas in higher vocational colleges, the school-enterprise cooperation, production and education integration do only involve in transferring students to enterprises for several weeks of practice and training, and a school-enterprise cooperation agreement signed, thus implementing the modern apprenticeship system. And students in higher vocational colleges also do not know what is the modern apprenticeship as an intern, and visiting play the main role in the practical learning of students in the enterprise largely not operating. It is difficult to get in touch with the actual work such as the practical learning of students who are major in mechanism design, manufacture and automation. First of all, after the students arrive at the enterprise, they dislike the environmental pollution of the factory and it is difficult to adapt to the working environment and cultural environment of the enterprise. Secondly, there exists a certain gap between the apprentice and the master. The enterprise masters are paid by the pieces and are unwilling to guide the students. In addition, the communication between the company and the school is difficult, and the enterprise masters are taught at the school, and the professional teachers cannot participate in the study. The theoretical classroom of professional teachers cannot be communicated (in time), which makes it difficult to reach a consensus for enterprises and schools on the true meaning of modern apprenticeship.

\subsection{Lack of policy and institutional guarantees}

Many western countries regard modern apprenticeship as an important national development strategy, and have a complete system in laws, regulations, financial guarantee and other aspects. Meanwhile, they have a clear tendency to participate in education in policies and systems, making enterprises willing to participate in talent cultivation, thus promoting the effective implementation of modern apprenticeship. Our country has launched a series of regulations and system at the national level; the provincial education 
departments also carry out and implement the relevant measures of modern apprenticeship according to the guidance opinions from state. However, most of them do not guarantee the dual-subject rights responsibility of enterprises and schools, and there are many measures to promote modern apprenticeships, such as the establishment of enterprise compensation funds. In the case of such a poor communication between the enterprise and the government, if the government policy and system are still lacking, the modern apprenticeship will inevitably flow into empty talk.

3.3 The enterprise pursues the maximization of interests, and the goals of both the university and the enterprise are inconsistent, resulting in the phenomenon of "two cold and two hot"

As a for-profit enterprise, pursuing the maximization of interests is the ultimate goal of any enterprise, while higher vocational colleges take the training of technical and technical talents adapting to the development needs of vocational positions as the ultimate goal. From the perspective of the way to maximize the benefits of enterprises and the training objectives of higher vocational colleges, the demands of the two are consistent. However, enterprises pay more attention to the return on investment and profit rate. It is difficult to accept students to practice in enterprises. In order to cultivate professional talents that meet the needs of enterprises, colleges and universities must determine the professional setting, teaching process and course content according to the needs of social and economic development and professional positions. The profession and industry, curriculum content and professional standards, teaching process and production process must be closely integrated. These must be done jointly by schools and enterprises. After investigation, as the main body of the modern apprenticeship system, only $20 \%$ of the students is willing to participate in the modern apprenticeship mode training, and then there will be a phenomenon of "two colds and two fevers" in which the government is hot, the school is hot and the enterprise is cold, and the students are cold.

\subsection{Low teaching level of "double-profession and double-qualified teachers"}

Modern apprenticeship needs the professional teachers with high level of "double" ability in higher vocational colleges and universities, however, there is clear tendency named "distorted phenomenon" to degree not ability in vocational colleges generally. From the perspective of college recruitment in recent years, the first condition must be a graduate degree. What is important is that the promotion of the teacher's professional title is related to the teacher's academic qualifications, which leads the teacher to focus on improving his or her academic qualifications, ignoring the improvement of practical skills and academic standards. Teachers are unwilling and do not want to participate in corporate practice, so that the proportion of "double-qualified" teachers in colleges and universities is far less than the documentation requirements.

Modern apprenticeship can't be achieved only by the school's professional theory teachers, which requires the high-level and highly skilled front-line engineers (teachers) from enterprise to participate in the teaching. However, highly skilled and high-level engineers in the enterprise are obviously insufficient, and the enterprise's masters are either of poor quality or of low professional skills. Even if there are highlevel enterprise masters, it is impossible for them to become a "master" of modern apprenticeship because the enterprise has no relevant welfare guarantee for them. Therefore, it is difficult for schools and enterprises to meet the dual teacher team of modern apprenticeship in the implementation level.

\section{The Implementation Path of Modern Apprenticeship in Vocational Colleges}

\subsection{Relevant laws and regulations of modern apprenticeship led and improved by government}

Modern apprenticeship comes from western countries, such as "dual system" in Germany, Britain's modern apprenticeship and Australia's "new apprenticeship". No matter which country's apprenticeship is, the government has played an irreplaceable role in the implementation and effective promotion of apprenticeship. Since the first batch of modern apprenticeship pilots in China in 2014, China has promulgated the Opinions on Launching the Pilot Program of Modern Apprenticeships, Opinions of the Ministry of Education on Deepening the Promotion of Vocational Education Group Management, Notice on Launching the Pilot Program of Modern Apprenticeship, Notice on Launching Pilot Work on New 
Apprenticeships in Enterprises as well as documents relating to the promotion of modern apprenticeships, such as the Several Opinions on Deepening the Integration of Production and Education, which provides policy guarantee for the smooth development of the modern apprenticeship system. Some relevant documents are issued in various provinces and cities according to some relevant national policies for the implementation of modern apprenticeship, but these documents are opinions and suggestions from macro aspects like the effective implementation of modern apprenticeship etc., not a specific laws and regulations which can effectively mobilize enterprise or vocational colleges to take the initiative to participate in modern apprenticeships. So nation or cities should fully investigate the practices of modern apprenticeship implementation effect in the process of implementation of modern apprenticeship, and promulgate the relevant laws and regulations according to the problems appeared, clarify the rights and obligations of the participants from the government, enterprises, schools and students, meanwhile, improve related mechanism which can motivate the enterprises to participate in the modern apprenticeship education, give out related regulations of giving the benefit for the enterprise, such as tax reduction and exemption, rewards or funds allowance etc., and carry out the related laws and regulations to the whole province to follow. We should establish an effective monitoring and evaluation mechanism to ensure the implementation of the modern apprenticeship system, ensure the healthy and sound development of the modern apprenticeship system in the institutional cage, and at the same time, it is necessary for higher vocational colleges to make full use of the independent recruitment policy to develop a modern apprenticeship talent training model for vocational high schools and regular high schools.

\subsection{Efficient path to implement modern apprenticeship in higher vocational colleges}

The aim of talents cultivating in higher vocational colleges is to cultivate high-quality technical and technical talents who can adapt to the ability of professional position. The realization of this training goal cannot be realized simply by the traditional education model. It is necessary to make full use of enterprise resources, integrate production and education, deepen school-enterprise cooperation and actively carry out modern apprenticeship pilot work. As the main body of modern apprenticeship, higher vocational colleges should actively communicate with enterprises and explore effective ways to implement modern apprenticeship in China on the basis of referring to the successful experience of modern apprenticeship at home and abroad in the implementation process of modern apprenticeship talent training mode.

4.2.1 Make full use of the policy of "enrollment is enrollment, entering the school is entering the factory", and carry out the modern apprenticeship training mode

The Ministry of education points out that vocational college should actively carry out the mode that "recruit students are like recruitment in factory, enrolled into school is the like in factory and schoolenterprise joint training', Vocational colleges should make full use of independent enrollment policy, recruit needed professionals from all walks of the society then train them, and cooperate with enterprise in the process of implementation, to establish "ordering" personnel training mode, training talents together with the enterprise in the implementation of modern apprenticeship. Under the conditions of mastering the necessary professional theoretical knowledge, students are delegated to the company for professional skills training. The designated enterprise masters bring apprenticeships, impart professional skills, and give students the necessary salary treatment. Enrollment means recruiting and entering the school equals to entering the factory, so that students can get in touch with the actual work position of the enterprise and improve their ability to adapt to professional positions.

4.2.2 Carry out the Training Mode of Modern Apprenticeship by "Introducing Enterprises into the School"

Deep cooperation between schools and enterprises and integration of production and education are the development direction of career education, and modern apprenticeship is an effective way to deepen integration of school-enterprise cooperation, production and education. Vocational colleges must adhere to the companies into the school, the school introduced market guiding ideology; adhere to the main leading idea like guiding enterprise to school and guiding school to market. We should make full use of social resources, gather all parties' strengths, rely on industry-run professionalism, combine supply-side structural reforms, and implement school-enterprise joint education to implement the modern 
apprenticeship training model of "factory middle school, school-based factory". In the case of policy conditions, higher vocational colleges may adopt the "shareholding system", "lease system", "coconstruction system" and other forms to "enter enterprises into the school" ${ }^{[4]}$. In the case of making full use of resources inside and outside the school, we can meet the production needs of enterprises and realize the authenticity and diversity of the training base. In the implementation process, we always adhere to the goal of school-enterprise cooperation and common education, and focus on educating people, while standardizing management according to the contract.

4.2.3 Establish the Practice and Training Base and Carry out the Training Mode of Modern Apprenticeship Jointly

The practice and training base is an important strategic position for higher vocational colleges to cultivate high-quality skilled talents, and it is an important place to cultivate students' professional ability, practical ability, innovation awareness and entrepreneurial ability, as well as a good place to improve teachers' professional practice ability and "dual ability" quality. Vocational colleges and universities should make full use of various resources, actively communicate, and establish training bases on the principle of "win-win cooperation". By training and digging outstanding professional talents, enterprises can meet the needs of enterprise, and gradually improve the structure and quality of employees. Meanwhile, vocational colleges also achieve the goal of professional talent cultivation and improve the professional practice skills of teachers.

\subsection{Strengthen the construction of "double-qualified teachers and dual-qualified teachers"}

The training mode of modern apprenticeship talents has the characteristics of "educating people by double type teachers", that is, teachers in Higher Vocational Colleges and teachers in enterprises. From the current point of view, university teachers have high academic qualifications, theoretical strong, but lack of professional practical skills, and enterprise teachers have high professional skills and practical experience but their academic qualifications and academic qualifications are low. As far as the actual situation concerned, in order to meet the training pilot project of modern apprenticeship, it is not rare for higher vocational colleges to falsely report the proportion of teachers with "dual ability and dual ability" ${ }^{[5]}$. In the process of training modern apprenticeship talents, the "double-skilled dual-energy" faculty is the key. To this end, schools must improve the theoretical and practical abilities of professional teachers through various lectures, professional training, old-fashioned, and off-campus participation in corporate social practice training and training. At the same time, the school must hire first-line experts and technical experts to undertake professional internship training courses, and require professional teachers to learn together and improve professional practice skills.

\subsection{Establish talent training mode of modern apprenticeship with enterprises jointly}

The successful implementation of the modern apprenticeship system must establish the modern apprenticeship talent training mode jointly built by both the university and the enterprise. In the implementation process of modern apprenticeship, it is necessary to realize the connection between specialty and industry, course content and professional standard, teaching process and production process ${ }^{[6]}$. On the basis of full market research, based on the modern apprenticeship concept, the curriculum system and innovative education teaching model should be reconstructed. At the same time, enterprises must participate in the professional talent training program, curriculum system construction, course content and teaching process. In the course system of the talent training program, a school-enterprise cooperation development course is set up, and on-the-spot teaching is carried out on the teaching organization form and teaching method and the class is moved to the factory and the training room. In the teaching content, the real business of the enterprise will be brought into the classroom, the teaching process and the production process will be orderly linked up, and the two different educational platforms of the school and the enterprise will be fully utilized.

\section{Conclusion}

At present, the pilot work of modern apprenticeship in higher vocational colleges is being carried out in an orderly way, and the pilot vocational colleges are constantly trying the path of modern 
apprenticeship and school-enterprise cooperation model. Although certain achievements have been made, there are still many problems. With the deepening integration of school-enterprise cooperation, talent training mode of modern apprenticeship in higher vocational colleges will be improved continuously, participation level of enterprise will be improved continuously, and more high-quality technical and technical talents who can meet professional abilities and positions will be trained well.

\section{Acknowledgment}

Project approval of the second teaching reform and education quality evaluation research of Liaoning education evaluation association (project number: PJHYZD17081)

\section{References}

[1]. Ministry of education. Opinions on deepening career education teaching reform and comprehensively improving the quality of talent training, September 11, 2015.

[2]. zhou Jianru. Exploration and practice of modern apprenticeship talent training mode [J]. Journal of Qingdao vocational and technical college,2017,30 (1).

[3]. Du Xiaoxia. Existing problems and countermeasures of modern apprenticeship in vocational colleges [J]. Shanxi architecture,2016,42(33).

[4]. Yao Zheng. Practical research on the connection between modern apprenticeship and schoolenterprise [J]. Teaching education (higher education BBS),2017,(10).

[5]. Chen Yuebing. Research on some issues of shaping China's modern apprenticeship with "one master and multiple elements" [J]. China occupational technology education,2017,(8).

[6]. Xu Chun. Current research on the implementation of modern apprenticeship in vocational colleges [D]. Yangzhou: Yangzhou university,2016. 